\title{
SPLIT SKIN GRAFT AND THE TREATMENT OF PRESSURE SORES
}

\author{
By Isaac M. NuSEIBeH, M.B.Ch.B., L.M.S.S.A., F.R.C.S. \\ Registrar at The Liverpool Regional Paraplegic Centre, Southport (England)
}

Most of the many ways of treating pressure sores, ranging from simple dressings. to sophisticated flap repairs, and even amputation, have been used in this Centre. Many authorities today (Buchan, I963; Bailey, I968; McGregor, I968) would not accept the use of split skin grafts as a definitive repair of pressure sores and this view has prompted us to review our own cases in order to assess the value of this simple procedure.

\section{MATERIAL}

Since 1945 when the Southport Paraplegic Centre was opened, and up until I97I, 985 patients have been admitted for treatment of paraplegia. Of these, there were 73 who had split skin grafts applied to their pressure sores in various sites. We have reviewed all these cases under varying headings according to the sites, that is sacral, trochanteric, etc.

In the 33 patients in whom there was more than one pressure sore, each sore has been included in its appropriate group, so that the total number of sores will be seen to exceed the number of patients. We have taken two criteria for a successful result. First, that the sore healed within 6 weeks of the skin grafting, and second, that it remained healed for at least I year.

\section{RESULTS}

It will be seen from Figures I to 5 that the success rate varied from site to site. Thus Figure I shows that of the 49 trochanteric sores, 26 fulfilled the criteria for success, while 23 failed to heal with split skin grafts.

Of the 15 ischial sores, nine remained healed and six failed as shown in Figure 2.

Of the 28 sacral sores, I9 healed and only nine failed (Fig. 3).

Figure 4, illustrates the results of the five patients with sores over the malleoli, where four healed and one failed.

Figure 5, represents a miscellaneous group which includes sores on the knees, chest, etc. All eight sores responded favourably to split skin grafts.

Figure 6, presents the results in those cases with a single sore regardless of their site, where it will be seen that of the 40 patients, as many as 27 achieved a successful result. This is contrasted with Figure 7, which shows 33 patients with multiple pressure sores. Only I I of these patients achieved a successful result in all their sores, while 22 had a recurrence in at least one of the sores, requiring further plastic procedures.

$\mathrm{I} 2 / \mathrm{I}-\mathrm{A}$ 


\section{DISCUSSION}

It will be seen from the results that a surprisingly high proportion of patients can hope for a successful result in the treatment of pressure sores by split skin

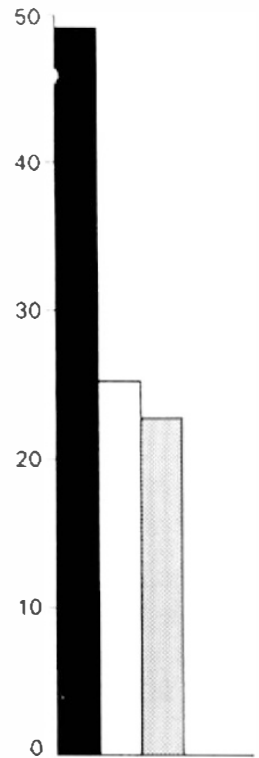

FIG. I

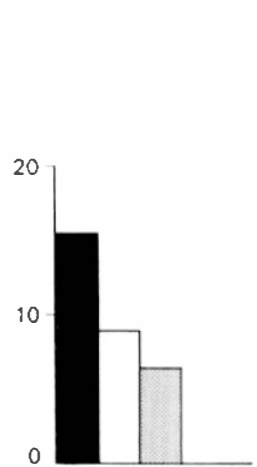

I'ṬG. 2

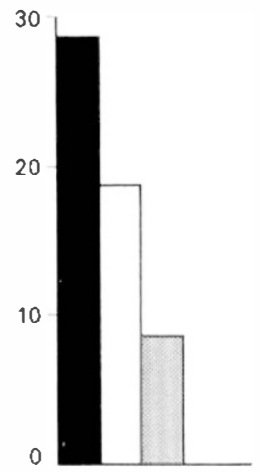

FIG. 3

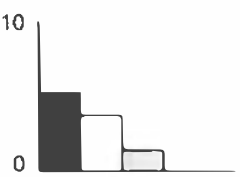

FIG. +

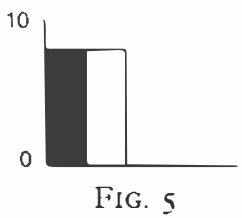

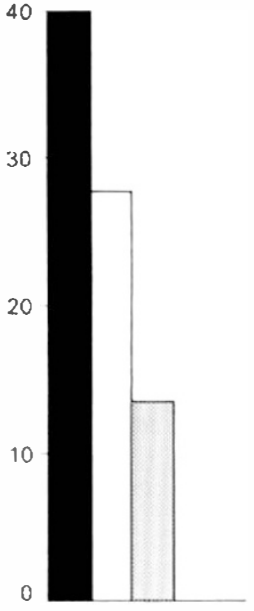

FIG. 6

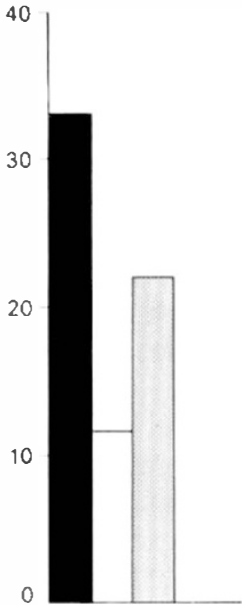

Fig. 7

\section{Number of pressure sores}

Number of pressure sores with successful results

$\square$ Number of sores which have falled 
grafts. Conversely it is also clear from our experience that it is highly unlikely that conservative treatment will be successful when a split skin graft has failed.

It is of obvious importance to be able to recognise these patients with pressure sores in whom split skin grafts can be expected to provide a definite repair. An examination of our cases suggests several factors. The most important of these is multiplicity of sores. It has been shown that the success rate is reversed in patients with multiple pressure sores as compared with those patients with a single sore (I I out of 33 as compared with 27 out of 40). We have considered why this should be so and have come to certain conclusions. First, those patients presenting multiple pressure sores are more often anaemic, with low plasma proteins and in poor general condition. They are frequently less able or prepared to take precautions to prevent the development of pressure sores, so that even when primary healing has been achieved, they are more liable to suffer a recurrence after discharge from the Centre. Second, multiple pressure sores make nursing care difficult, due to the fact that there are fewer positions in which the patient can be nursed without traumatising the grafted areas. Not infrequently, the prone position is the only one available, and this is one which many patients find intolerable, or even impossible due to fixed flexion contractures.

The site of the pressure sores appears also to have some bearing on the results of split skin grafts. For example, sores on the sacral areas are seen to respond very well. It also appears from our results that the ischial sores responded well to split skin grafts. We feel this is a biased impression resulting from our policy in the treatment of ischial sores. Split skin grafts have been used almost exclusively on those cases with very superficial ischial sores. Where the sore has been deeper we have tended to proceed directly to excision of the sore and repair by direct suture or a flap and/or ischietomy.

Trochanteric sores can be expected to do well when they are superficial, or where there is considerable soft tissue padding surrounding the ulcer, so that the graft will lie in the depth of the sore, and therefore not be subject to direct pressure. Obviously the presence of heterotopic bone or a large and prominent greater trochanter protruding from the base of the ulcer will militate against a successful result. These are the cases on whom it will be necessary to remove the heterotopic bone or the prominent bone, and to provide a thick covering pad of skin and subcutaneous tissue in the form of a flap.

It goes without saying, that successful results cannot be expected in those cases in whom there is an infected bursa, bare bone or an open joint lying in the base of the sore.

\section{SUMMARY}

Split skin graft has been used in the Southport Regional Paraplegic Centre as a definitive method of repair for different types of pressure sores with an appreciable rate of success. The causes of failure of this method of treatment have been discussed.

\section{RÉSUMÉ}

Les plasties par lambeaux de peaux ont été utilisées au Southport Régional Centre comme méthode définitive de réparation pour différents types d'escarres avec un taux de succès appréciable. Les causes d'insuccès par cette méthode ont été discutées dans le texte. 


\section{ZUSAMMENFASSUNG}

Es wird über die Technik der Spalthauttransplantation berichtet, eine Methode, die sich für verschiedene Formen von Druckgeschwüren erfolgreich erwiesen hat. Die Ursachen von Misserfolg mit dieser Methode werden diskutiert.

Acknowledgements. I wish to thank Mr. D. O. Maisels, Consultant Plastic Surgeon of The Liverpool Regional Paraplegic Centre, for his help and direction, and also Mr. K. R. Krishnan, Consultant in Charge of that Centre, for his support and for studying patients under his care. I gratefully acknowledge the help of Miss C. Magelione, Secretary at the Liverpool Regional Paraplegic Centre, and Miss C. J. Tuset, Secretary at The National Spinal Injuries Centre, Stoke Mandeville Hospital, Aylesbury, Bucks.

\section{REFERENCES}

BAILEY, B. N. (1967). Bedsores, pp. 45-52. London: Edward Arnold.

Buchan, A. C. (1963). The plastic surgeon and paraplegia. In Spinal Injuries, Proceedings of a Symposium, ed. Phillip Harris, pp. I31-1 32. Edinburgh Royal College of Surgeons.

MCGREgor, I. A. (I972). Fundamental Techniques of Plastic Surgery, pp. I93-I94. Edinburgh: Churchill Livingstone. 